\title{
Synthesis and electrochemical properties of an aluminum hexafluorophosphate electrolyte
}

\author{
Xiaoyu Wen, ${ }^{\dagger}$ Jian Zhang, ${ }^{\S}$ Hewei Luo, ${ }^{\|}$Charlene Tsay, ${ }^{\ddagger}$ Huanhuan Jiang, ${ }^{\dagger}$ Ying-Hsuan Lin, ${ }^{\ddagger}$ \\ Juchen Guo ${ }^{* \dagger \S}$ \\ ${ }^{\dagger}$ Department of Chemical and Environmental Engineering, University of California, Riverside, CA 92521, \\ United States. \\ ${ }^{\S}$ Materials Science and Engineering Program, University of California, Riverside, CA 92521, United States. \\ "School of Material and Chemical Engineering, Zhengzhou University of Light Industry, Zhengzhou \\ 450002, China. \\ ${ }^{\ddagger}$ Department of Chemistry, University of California, Riverside, CA 92521, United States. \\ Department of Environmental Sciences, University of California, Riverside, CA 92521, United States.
}

\section{KEYWORDS}

Aluminum hexafluorophosphate, $\mathrm{Al}$ deposition, Al-ion electrolyte, chloride-free

\begin{abstract}
We report the first synthesis of aluminum hexafluorophosphate $\left(\mathrm{Al}_{(}\left(\mathrm{PF}_{6}\right)_{3}\right)$ and its electrochemical properties in dimethyl sulfoxide (DMSO). The single crystal structure of the synthesized $\mathrm{Al}_{(}\left(\mathrm{PF}_{6}\right)_{3}$ is revealed as $\mathrm{Al}\left(\mathrm{PF}_{6}\right)_{3} \cdot(\mathrm{DMSO})_{6}$, and $0.25 \mathrm{M} \mathrm{Al}\left(\mathrm{PF}_{6}\right)_{3}$ in $\mathrm{DMSO}$ with high ionic conductivity is obtained. With characterizations including nuclear magnetic resonance spectroscopy, scanning electron microscopy, and X-ray photoelectron spectroscopy, we demonstrate the reversibility of Al deposition-stripping in the electrolyte, which can be improved by triethylaluminium as the electrolyte additive. Finally, the side reaction involving DMSO decomposition to form aluminum oxide during $\mathrm{Al}$ deposition is identified by gas chromatography/electron ionization-mass spectrometry.
\end{abstract}

\section{INTRODUCTION}

To date, the electrochemical deposition of aluminum (Al) can only be achieved in electrolytes based on aluminum halides, mainly aluminum chloride $\left(\mathrm{AlCl}_{3}\right){ }^{1-}$

${ }^{4}$ Regardless the formulas of the electrolytes, which are either $\mathrm{AlCl}_{3}$-containing deep eutectic systems or $\mathrm{AlCl}_{3}$ solutions in organic solvents, the only known active species to deposit $\mathrm{Al}$ are Lewis acidic chloroaluminate anions $\mathrm{Al}_{2} \mathrm{Cl}_{7}^{-}$and $\mathrm{Al}_{3} \mathrm{Cl}_{10^{-}}$(the former is the dominating species reported in the literature). ${ }^{5-8}$ The corrosive nature of the chloride makes the current $\mathrm{Al}$ electrolytes not ideal, particularly aiming to the emerging research on rechargeable $\mathrm{Al}$ batteries. ${ }^{9-10} \mathrm{~A}$ number of studies also indicate that the current electrolytes are not chemically compatible with transition metal oxide, chloride or sulfide cathode materials. ${ }^{11-14}$ Furthermore, the electrochemical stability of these electrolytes is limited by the anodic generation of chlorine..$^{15}$ Therefore, the development of chloridefree $\mathrm{Al}$ electrolyte is critical to the research progress on rechargeable $\mathrm{Al}$ batteries.

Inspired by the Li-ion electrolytes using simple salts, we here propose an $\mathrm{Al}$ electrolyte based on aluminum hexafluorophosphate $\left(\mathrm{Al}\left(\mathrm{PF}_{6}\right)_{3}\right)_{\text {. In }}$ the proposed electrolyte, $\mathrm{Al}^{3+}$ ions can be dissociated from the $\mathrm{PF}_{6}{ }^{-}$ anions by solvation of polar solvent molecules, instead of forming chloroaluminate complexes. Among the common weakly coordinating anions, bis(trifluoromethanesulfonyl)imide (TFSI ${ }^{-}$) may possess the highest dissociation constant, however, it is known that $\mathrm{TFSI}^{-}$can be reduced electrochemically and chemically by metals including Al. ${ }^{16-19}$ On the other hand, $\mathrm{PF}_{6}{ }^{-}$anion strikes a good balance between 
dissociation constant and mobility as well as stability. ${ }^{20}$ In this study, we report the synthesis of electrochemical properties of $\mathrm{Al}\left(\mathrm{PF}_{6}\right)_{3}$ for the first time.

\section{- RESULTS AND DISCUSSION}

We synthesized $\mathrm{Al}\left(\mathrm{PF}_{6}\right)_{3}$ through the reaction between ammonium hexafluorophosphate $\left(\mathrm{NH}_{4} \mathrm{PF}_{6}\right)$ and triethyl-aluminum $\left(\mathrm{Et}_{3} \mathrm{Al}\right)$ as shown in Reaction 1 and detailed in the Supporting Information. The selection of the solvent of this reaction are restricted by the compatibility to $\mathrm{Et}_{3} \mathrm{Al}$ and the solubility of $\mathrm{Al}\left(\mathrm{PF}_{6}\right)_{3}$ : $\mathrm{Et}_{3} \mathrm{Al}$ is very active towards olefinic groups, carbonyl groups, primary and secondary amine groups, and hydroxyl groups. ${ }^{21}$ In addition, strong coulombic attraction between $\mathrm{Al}^{3+}$ and the anion results to much lower solubility of $\mathrm{Al}\left(\mathrm{PF}_{6}\right)_{3}$ in comparison to its monovalent analog. Thereby, we found dimethyl sulfoxide (DMSO) may be the only proper solvent with good solubility of $\mathrm{Al}\left(\mathrm{PF}_{6}\right)_{3}$ and compatibility with $\mathrm{Et}_{3} \mathrm{Al}$.

$$
\mathrm{Et}_{3} \mathrm{Al}+3 \mathrm{NH}_{4} \mathrm{PF}_{6} \rightarrow \mathrm{Al}\left(\mathrm{PF}_{6}\right)_{3}+3 \mathrm{NH}_{3} \uparrow+3 \mathrm{C}_{2} \mathrm{H}_{6} \uparrow
$$

After the synthesis, the single crystals of $\mathrm{Al}\left(\mathrm{PF}_{6}\right)_{3}$ were obtained by slow evaporation of a saturated solution of $\mathrm{Al}\left(\mathrm{PF}_{6}\right)_{3}$ in DMSO $(0.25 \mathrm{M})$ at $90{ }^{\circ} \mathrm{C}$ for 2 days. The crystal structure was determined by X-ray diffraction analysis. As illustrated in Figure 1, the single crystal of $\mathrm{Al}\left(\mathrm{PF}_{6}\right)_{3}$ consists of $\mathrm{Al}^{3+}$ cations coordinated by six DMSO molecules. Three $\mathrm{PF}_{6}{ }^{-}$anions are located at approximately $6.6 \AA$ from the $\mathrm{Al}^{3+}$ cation. The detailed crystal structure information of $\mathrm{Al}\left(\mathrm{PF}_{6}\right)_{3} \cdot(\mathrm{DMSO})_{6}$ can be found in the Supporting Information. The ionic conductivity of $0.25 \mathrm{M} \mathrm{Al}\left(\mathrm{PF}_{6}\right)_{3}$ in $\mathrm{DMSO}$ is $0.327 \mathrm{~S} \mathrm{~cm}^{-}$ ${ }^{1}$, which is close to the conductivity of $1 \mathrm{M} \mathrm{LiPF}_{6}$ in DMSO $\left(0.336 \mathrm{~S} \mathrm{~cm}^{-1}\right)$ (The conductivity measurement is in Figure $\mathbf{S 1}$ in the Supporting Information).

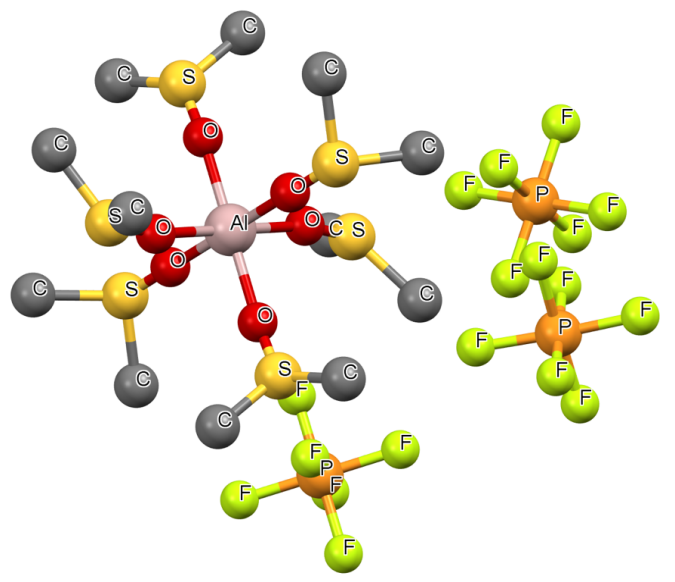

Figure 1. X-ray single crystal structure of $\mathrm{Al}\left(\mathrm{PF}_{6}\right)_{3} \cdot(\mathrm{DMSO})_{6}$. (Hydrogen atoms are omitted for clarity.)

The composition of the electrolyte is further identified by the liquid-state nuclear magnetic resonance (NMR) spectroscopy. The ${ }^{27} \mathrm{Al}$ NMR spectrum (Figure 2a) shows a sharp peak at $3.18 \mathrm{ppm}$ corresponding to the $\mathrm{Al}^{3+}$ cations coordinated by six DMSO molecules (in a 6-coordination environment). ${ }^{22} \mathrm{Al}$ peak associated with $\mathrm{Et}_{3} \mathrm{Al}$ was not detected. In Figure 2b, ${ }^{1} \mathrm{H}$ NMR spectrum shows two close singlets assigned to free DMSO at $2.52 \mathrm{ppm}^{23}$ and DMSO coordinated to $\mathrm{Al}^{3+}$ at $2.90 \mathrm{ppm}$. The integration ratio of coordinated DMSO to free DMSO is $1: 10$, which matches very well with the calculation based on the concentration $(0.25 \mathrm{M})$. The ${ }^{19} \mathrm{~F}$ (Figure 2c) and ${ }^{31} \mathrm{P}$ NMR spectra (Figure 2d) demonstrate the exist of $\mathrm{PF}_{6}{ }^{-}$anion. The doublet signal of $\mathrm{PF}_{6}{ }^{-}$in ${ }^{19} \mathrm{~F}$ NMR at $-72.47 \mathrm{ppm}$ and $-74.35 \mathrm{ppm}$ occurs due to the coupling effect with ${ }^{31} \mathrm{P}$ nuclei. Accordingly, the septet signal in ${ }^{31} \mathrm{P}$ NMR spectrum represents $\mathrm{PF}_{6}{ }^{-}$is also observed from -131 to -158 ppm. ${ }^{24}$ There is no major impurity detected in all NMR spectra, however, a very small peak in the ${ }^{19} \mathrm{~F}$ NMR at $157.58 \mathrm{ppm}$ was observed and it can be attributed to hydrogen fluoride (HF). ${ }^{25}$ The existence of HF in the solutions of hexafluorophosphate salts (e.g., $\mathrm{LiPF}_{6}{ }^{26-27}$, $\mathrm{NaPF}_{6}{ }^{28}$, and $\left.\mathrm{Mg}\left(\mathrm{PF}_{6}\right)_{2}{ }^{29}\right)$ is well known due to the existence of trace amount of water in the solution, although the DMSO solvent was distilled and sealed carefully before use. 

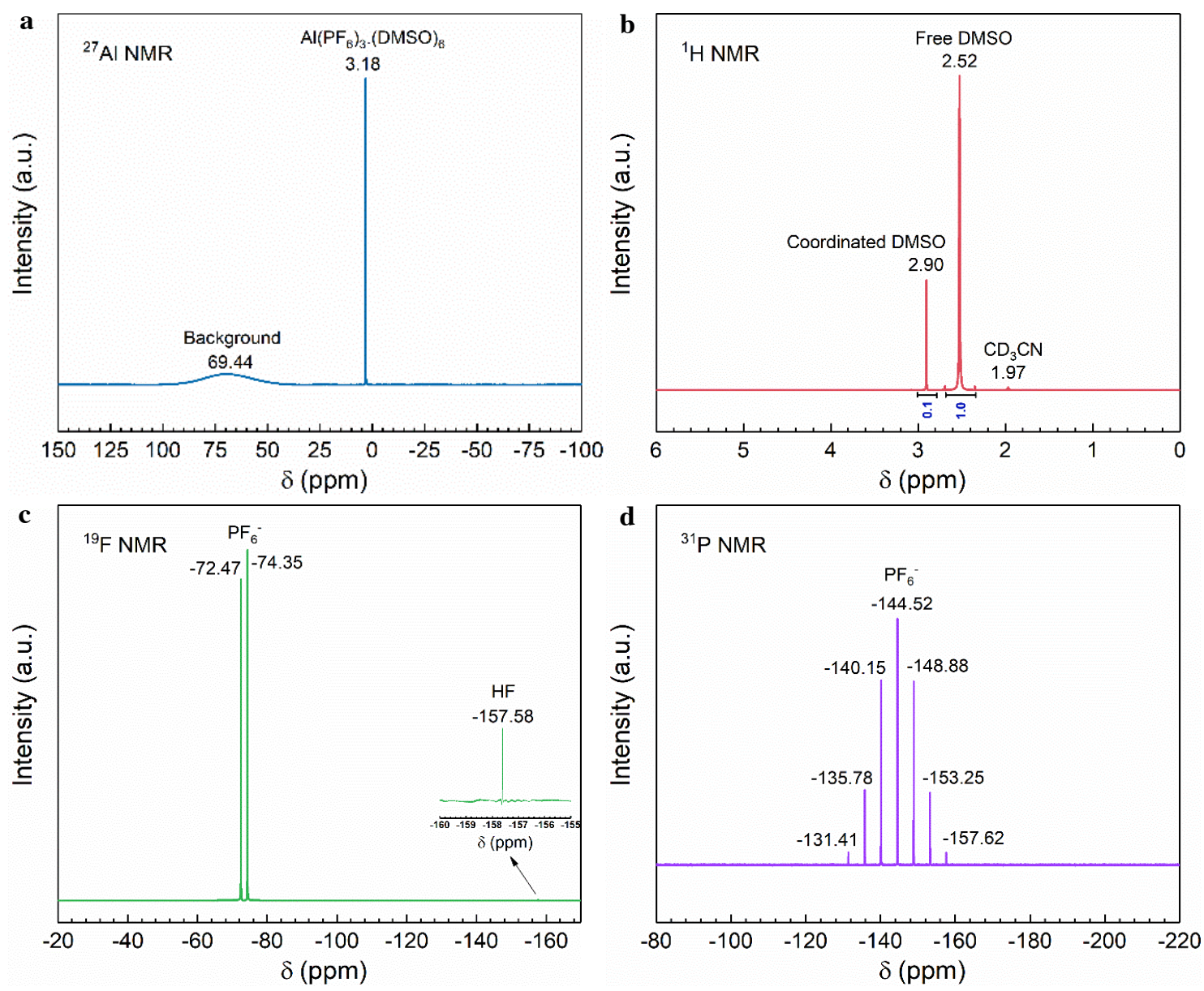

Figure 2. (a) ${ }^{27} \mathrm{Al}$, (b) ${ }^{1} \mathrm{H}$, (c) ${ }^{19} \mathrm{~F}$, and (d) ${ }^{31} \mathrm{P}$ NMR spectra of the pristine electrolyte of $0.25 \mathrm{M} \mathrm{Al}\left(\mathrm{PF}_{6}\right)_{3}$ in DMSO.

The cyclic voltammogram $(\mathrm{CV})$ of the $\mathrm{Al}\left(\mathrm{PF}_{6}\right)_{3}$ electrolyte obtained on a platinum working electrode in a three-electrode setup is shown in Figure 3a (red curve). A cathodic peak below $-0.5 \mathrm{~V}$ and an anodic peak at $1.3 \mathrm{~V}$ (both versus $\mathrm{Al}$ ) in the $\mathrm{CV}$ curve correspond to the reversible $\mathrm{Al}$ deposition-stripping. The chronopotentiometry curve of $\mathrm{Al}$ deposition on copper $(\mathrm{Cu})$ working electrode at $0.15 \mathrm{~mA} \mathrm{~cm}$ cm $^{-2}$ is plotted in Figure 3b (red curve), which demonstrates a stable overpotential of approximately $-1.1 \mathrm{~V}$ versus $\mathrm{Al}$ before it quickly increases after 3.5 hours. The deposition was characterized with scanning electron microscope (SEM) with energy dispersive X-ray (EDX) spectroscopy and X-ray photoelectron spectroscopy (XPS). As the SEM image in Figure 3c displays, the deposit obtained from the $0.25 \mathrm{M} \mathrm{Al}\left(\mathrm{PF}_{6}\right)_{3}$ in $\mathrm{DMSO}$ was small particles dispersed on the $\mathrm{Cu}$ substrate. The ${ }^{27} \mathrm{Al},{ }^{1} \mathrm{H},{ }^{19} \mathrm{~F}$, and ${ }^{31} \mathrm{P}$ NMR spectra of the electrolyte after deposition (Figure S2 in the Supporting
Information) detected no composition change expect that the ${ }^{27} \mathrm{Al}$ spectrum shows the appearance of hydrated $\mathrm{Al}^{3+}$ cations $\left(\mathrm{Al}\left(\mathrm{H}_{2} \mathrm{O}\right){ }_{6}{ }^{3+}\right)$ and the ${ }^{19} \mathrm{~F}$ spectrum indicates significant increase of $\mathrm{HF}$ concentration. Both observations indicate the trace amount of water in the electrolyte causes side reactions during the electrochemical deposition. Aurbach et al. demonstrated that a small amount of reducing agent such as di-nbutylmagnesium can react effectively with trace amount of water and lead to highly reversible Mg depositionstripping in the Mg-ion electrolyte. ${ }^{30}$ With a similarly strategy, we added $250 \mathrm{ppm} \mathrm{Et} 3 \mathrm{Al}$ to the $0.25 \mathrm{M}$ $\mathrm{Al}\left(\mathrm{PF}_{6}\right)_{3}$ electrolyte to eliminate the water content and improve the reactivity of $\mathrm{Al}$ deposition and stripping. Indeed, with the addition of $250 \mathrm{ppm} \mathrm{Et}_{3} \mathrm{Al}$, the current density of both peaks in the deposition-stripping CV (blue curve in Figure 3a) significantly increases and the overpotential of $\mathrm{Al}$ stripping is lowered by $0.7 \mathrm{~V}$ from that in the pristine electrolyte. The overpotential of the 
chronopotentiometry deposition of $\mathrm{Al}$ was also reduced by $0.5 \mathrm{~V}$ after the addition of $\mathrm{Et}_{3} \mathrm{Al}$ as presented in Figure 3b (blue curve). Furthermore, the distinctly different surface morphology of the $\mathrm{Al}$ deposit after adding $\mathrm{Et}_{3} \mathrm{Al}$ is shown in Figure 3d. Unlike the particle deposit from the pristine electrolyte, adding $\mathrm{Et}_{3} \mathrm{Al}$
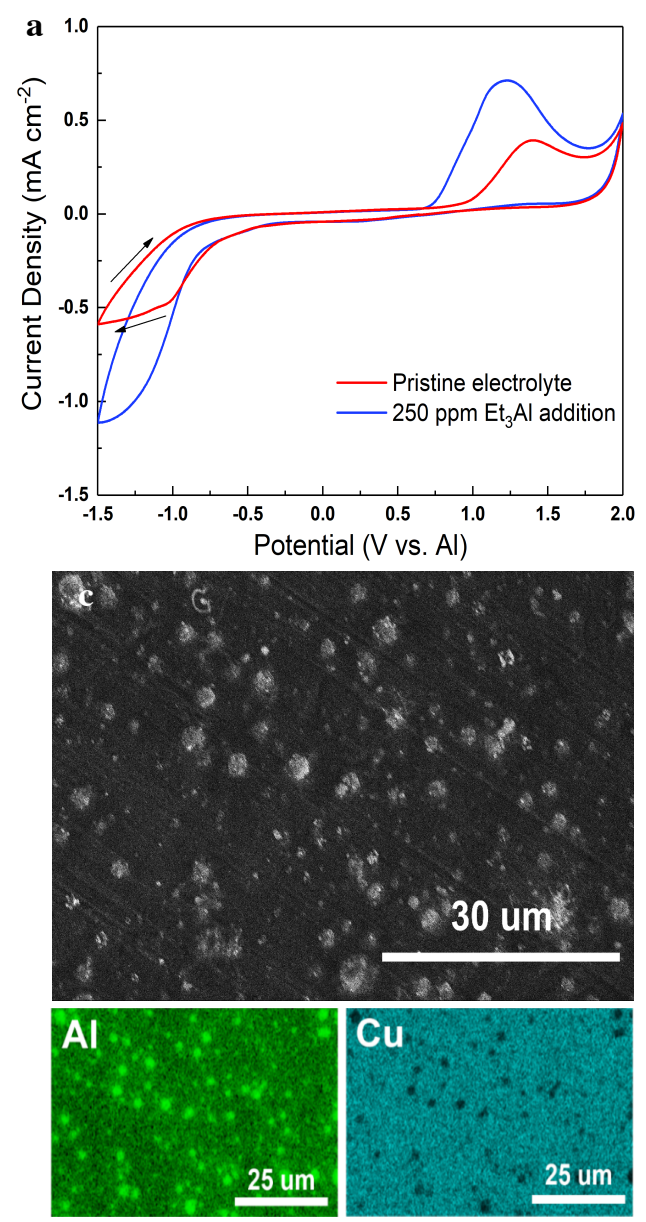

results to layered deposition with large area, suggesting more uniform and efficient electrodeposition process. Moreover, energy-dispersive X-ray spectroscopy (EDX) elemental mappings clearly display the distribution of the $\mathrm{Al}$ element on the $\mathrm{Cu}$ substrate. The EDX spectra are in the Supporting Information (Figure S3).
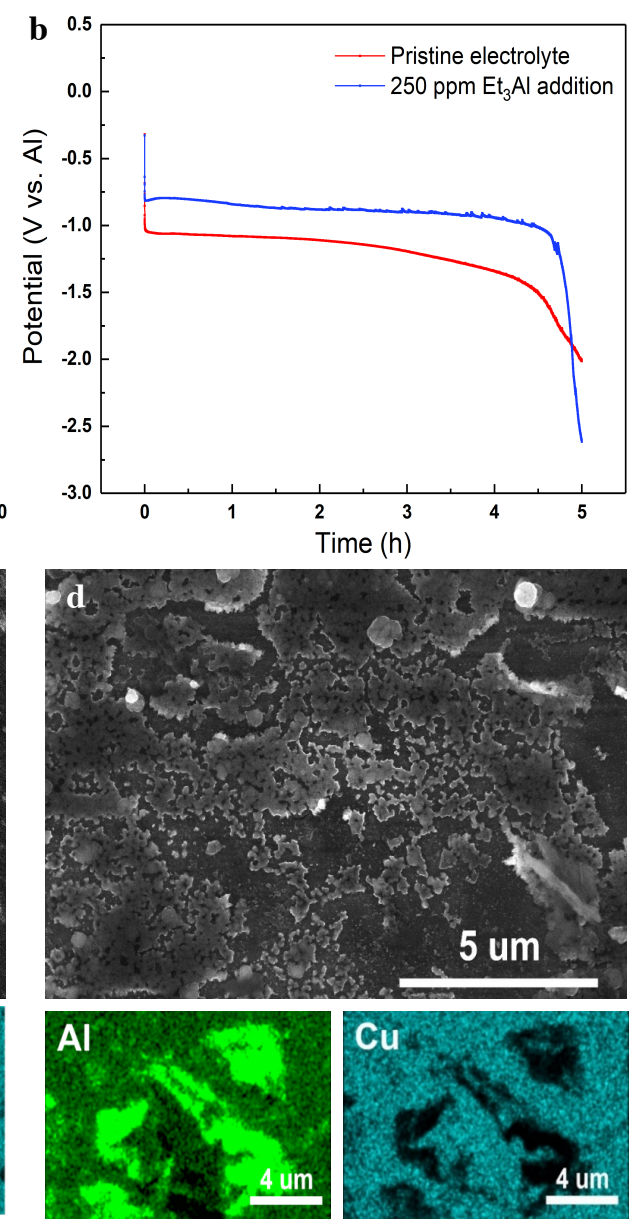

Figure 3. (a) $\mathrm{CV}$ scans at $25 \mathrm{mV} \mathrm{s}^{-1}$ in $0.25 \mathrm{M} \mathrm{Al}\left(\mathrm{PF}_{6}\right)_{3}$ in $\mathrm{DMSO}$ with and without $250 \mathrm{ppm} \mathrm{Et}_{3} \mathrm{Al}$ additive; (b) Chronopotentiometry curve at $-0.15 \mathrm{~mA} \mathrm{~cm}^{-2}$ in DMSO with and without $250 \mathrm{ppm} \mathrm{Et} 3 \mathrm{Al}$ additive; SEM images and EDX elemental mapping of $\mathrm{Al}$ deposit on $\mathrm{Cu}$ from $0.25 \mathrm{M} \mathrm{Al}\left(\mathrm{PF}_{6}\right)_{3}$ in $\mathrm{DMSO}$ (c) without and (d) with $250 \mathrm{ppm} \mathrm{Et}_{3} \mathrm{Al}$ additive.

The Al depositions are further analyzed with XPS to identify the composition of the deposits. Figure 4a shows Al 2p XPS spectra with depth profiling after electrodeposition from the electrolyte without $\mathrm{Et}_{3} \mathrm{Al}$ additive. Two deconvoluted peaks at 77.0 and $75.8 \mathrm{eV}$ in the spectrum of the pristine surface $(0 \mathrm{~min}$ argon sputtering) are attributed to aluminum fluoride $\left(\mathrm{AlF}_{3}\right)$ and aluminum oxide $\left(\mathrm{Al}_{2} \mathrm{O}_{3}\right)$, respectively. ${ }^{31}$ After sputtering for 2 min with argon, the relative intensity of the $\mathrm{Al}_{2} \mathrm{O}_{3}$ peak increased comparing to that of $\mathrm{AlF}_{3}$. A new peak at $74.8 \mathrm{eV}$, which can be assigned to the thin $\mathrm{Al}_{2} \mathrm{O}_{3}$ layer on $\mathrm{Al}$ metal, ${ }^{32}$ emerged in the spectrum. After argon sputtering for 18 minutes, consistent Al 2p spectrum can be obtained, in which the peak of thick $\mathrm{Al}_{2} \mathrm{O}_{3}$ diminished. Instead, the relative intensity of the peak of thin $\mathrm{Al}_{2} \mathrm{O}_{3}$ layer on $\mathrm{Al}$ metal significantly increased. Furthermore, a pair of peaks at $72.6 \mathrm{eV}$ (Al $2 \mathrm{p}_{3 / 2}$ ) corresponding to metallic $\mathrm{Al}$ emerged in the 
spectrum. $^{33}$ These observations indicate that the deposition of metallic Al may occur simultaneously with the formation of $\mathrm{Al}_{2} \mathrm{O}_{3}$ during the initial period of deposition. The $\mathrm{Al}$ and $\mathrm{Al}_{2} \mathrm{O}_{3}$ can subsequently react with $\mathrm{HF}$ in the $\mathrm{Al}\left(\mathrm{PF}_{6}\right)_{3}$ electrolyte to form $\mathrm{AlF}_{3}$, which appeared close to the surface of the deposit. Adding $\mathrm{Et}_{3} \mathrm{Al}$ significantly alleviate the formation of $\mathrm{AlF}_{3}$ as shown in Figure 4b. Comparing to the pristine surface deposited from the electrolyte without $\mathrm{Et}_{3} \mathrm{Al}$, the surface layer from the electrolyte with $\mathrm{Et}_{3} \mathrm{Al}$ shows weak $\mathrm{AlF}_{3}$ signal. More importantly, the peaks of metallic $\mathrm{Al}$ emerged only after sputtering for $2 \mathrm{~min}$ and there are no peaks of thick $\mathrm{Al}_{2} \mathrm{O}_{3}$ layer. These XPS results further confirm that the addition of $\mathrm{Et}_{3} \mathrm{Al}$ facilitates $\mathrm{Al}$ deposition by reducing $\mathrm{H}_{2} \mathrm{O}$ and the side reactions due to $\mathrm{HF}$. Unfortunately, the formation of $\mathrm{Al}_{2} \mathrm{O}_{3}$ seems an

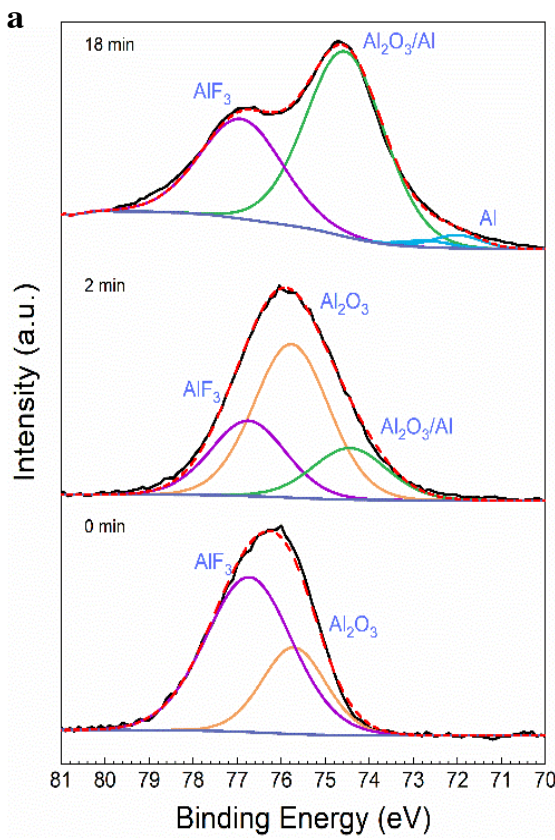

inherent parasitic reaction of $\mathrm{Al}$ deposition regardless $\mathrm{Et}_{3} \mathrm{Al}$ was added or not.

The possible mechanism of $\mathrm{Al}_{2} \mathrm{O}_{3}$ formation was probed by gas chromatography/electron ionizationmass spectrometry (GC/EI-MS) (Figure $\mathrm{S} 4$ in the Supporting Information) during chronopotentiometry deposition of Al. In both electrolytes with and without $\mathrm{Et}_{3} \mathrm{Al}$, gaseous dimethyl sulfide $\left(\mathrm{C}_{2} \mathrm{H}_{6} \mathrm{~S}, \mathrm{~m} / \mathrm{z}=62\right)$ was detected with GC/EI-MS during Al deposition. Therefore, the side reaction (or one of the side reactions) involving DMSO during electrodeposition is proposed as Reaction 2.

$$
2 \mathrm{Al}^{3+}+6 \mathrm{e}^{-}+3 \mathrm{C}_{2} \mathrm{H}_{6} \mathrm{OS} \rightarrow \mathrm{Al}_{2} \mathrm{O}_{3}+3 \mathrm{C}_{2} \mathrm{H}_{6} \mathrm{~S} \uparrow \quad \text { [2] }
$$

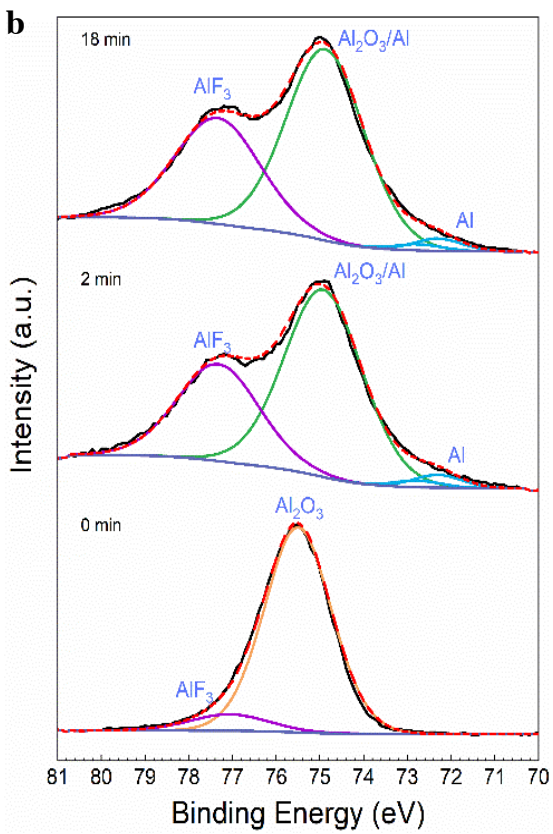

Figure 4. $\mathrm{Al} 2 \mathrm{p}$ XPS depth profiling analysis of the $\mathrm{Al}$ deposits from the electrolytes of $0.25 \mathrm{M} \mathrm{Al}\left(\mathrm{PF}_{6}\right)_{3}$ in $\mathrm{DMSO}$ (a)

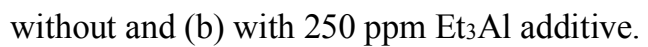

\section{CONCLUSION}

Our work demonstrates the first chloride-free $\mathrm{Al}$ electrolyte based on weakly coordinating $\mathrm{PF}_{6}{ }^{-}$anion. Electrochemical deposition-stripping of $\mathrm{Al}$ from the electrolyte of $\mathrm{Al}\left(\mathrm{PF}_{6}\right)_{3}$ in $\mathrm{DMSO}$ was demonstrated feasible, particularly after the removing the water impurity by adding a small amount of $\mathrm{Et}_{3} \mathrm{Al}$. We also found the $\mathrm{Al}$ deposition-stripping is undermined due to the continuous cathodic decomposition of DMSO on the electrode surface to form $\mathrm{Al}_{2} \mathrm{O}_{3}$. It would be difficult to find dissolvable and stable solvents for $\mathrm{Al}\left(\mathrm{PF}_{6}\right)_{3}$, therefore our future strategies is to substitute $\mathrm{PF}_{6}{ }^{-}$to more weakly coordinating and stable anion, which can be dissolved in the solvent with better cathodic stability.

\section{ASSOCIATED CONTENT}

\section{Funding Sources}

National Science Foundation: CBET-1751929 


\section{Notes}

The authors declare no competing financial interest.

\section{ACKNOWLEDGMENTS}

X. W. and J. G. acknowledge the financial support from U.S. National Science Foundation (NSF) CAREER program through grant number CBET-1751929. NMR measurements were performed at the Analytical Chemistry Instrumentation Facility at UCR, funded in part by NSF under grant number CHE-1626673. XPS was performed at the UC Irvine Materials Research Institute (IMRI) using instrumentation funded in part by the National Science Foundation Major Research Instrumentation Program under grant no. CHE1338173.

\section{- REFERENCES}

1. Ferrara, C.; Dall'Asta, V.; Berbenni, V.; Quartarone, E.; Mustarelli, P., Physicochemical Characterization of $\mathrm{AlCl}_{3}-1$-Ethyl-3methylimidazolium Chloride Ionic Liquid Electrolytes for Aluminum Rechargeable Batteries. J. Phys. Chem. C 2017, 121 (48), $26607-$ 26614.

2. Wang, H.; Gu, S.; Bai, Y.; Chen, S.; Zhu, N.; Wu, C.; Wu, F., Anion-effects on electrochemical properties of ionic liquid electrolytes for rechargeable aluminum batteries. J. Mater. Chem. A 2015, 3 (45), 22677-22686.

3. Coleman, F.; Srinivasan, G.; Swadzba-Kwasny, M., Liquid coordination complexes formed by the heterolytic cleavage of metal halides. Angew Chem Int Ed Engl 2013, 52 (48), 12582-6.

4. $\quad$ Li, M.; Gao, B.; Liu, C.; Chen, W.; Shi, Z.; Hu, X.; Wang, Z., Electrodeposition of aluminum from $\mathrm{AlCl} 3$ /acetamide eutectic solvent. Electrochim. Acta 2015, 180, 811-814.

5. Jiang, T.; Chollier Brym, M. J.; Dubé, G.; Lasia, A.; Brisard, G. M., Electrodeposition of aluminium from ionic liquids: Part I-electrodeposition and surface morphology of aluminium from aluminium chloride $\left(\mathrm{AlCl}_{3}\right)$-1-ethyl-3-methylimidazolium chloride ([EMIm]Cl) ionic liquids. Surf. Coat. Technol. 2006, 201 (1-2), 1-9.

6. Wang, Q.; Zhang, Q.; Lu, X.; Zhang, S., Electrodeposition of $\mathrm{Al}$ from chloroaluminate ionic liquids with different cations. Ionics 2017, 23 (9), 2449-2455.

7. Pradhan, D.; Reddy, R. G., Mechanistic study of $\mathrm{Al}$ electrodeposition from $\mathrm{EMIC}-\mathrm{AlCl}_{3}$ and $\mathrm{BMIC}-\mathrm{AlCl}_{3}$ electrolytes at low temperature. Mater. Chem. Phys. 2014, 143 (2), 564-569.

8. Wen, X.; Liu, Y.; Xu, D.; Zhao, Y.; Lake, R. K.; Guo, J., Room-Temperature Electrodeposition of Aluminum via Manipulating Coordination Structure in $\mathrm{AlCl}_{3}$ Solutions. J Phys Chem Lett 2020, 11 (4), 1589-1593.

9. Tseng, C.-H.; Chang, J.-K.; Chen, J.-R.; Tsai, W. T.; Deng, M.-J.; Sun, I. W., Corrosion behaviors of materials in aluminum chloride-1-ethyl-3-methylimidazolium chloride ionic liquid. Electrochem. Commun. 2010, 12 (8), 1091-1094.

10. Reed, L. D.; Menke, E., The Roles of $\mathrm{V}_{2} \mathrm{O}_{5}$ and Stainless Steel in Rechargeable Al-Ion Batteries. J. Electrochem. Soc. 2013, 160 (6), A915-A917.

11. Wen, X.; Liu, Y.; Jadhav, A.; Zhang, J.; Borchardt, D.; Shi, J.; Wong, B. M.; Sanyal, B.; Messinger, R. J.; Guo, J., Materials Compatibility in Rechargeable Aluminum Batteries: Chemical and Electrochemical Properties between Vanadium Pentoxide and Chloroaluminate Ionic Liquids. Chem. Mater. 2019, 31 (18), 72387247.
12. Donahue, F. M.; Mancini, S.; Simonsen, L., Secondary aluminium-iron (III) chloride batteries with a low temperature molten salt electrolyte. J. Appl. Electrochem. 1992, 22 (3), 230-234.

13. Mori, T.; Orikasa, Y.; Nakanishi, K.; Kezheng, C.; Hattori, M.; Ohta, T.; Uchimoto, Y., Discharge/charge reaction mechanisms of $\mathrm{FeS}_{2}$ cathode material for aluminum rechargeable batteries at $55^{\circ}$ C. J. Power Sources 2016, 313, 9-14.

14. Zafar, Z. A.; Imtiaz, S.; Razaq, R.; Ji, S.; Huang, T.; Zhang, Z.; Huang, Y.; Anderson, J. A., Cathode materials for rechargeable aluminum batteries: current status and progress. $J$. Mater. Chem. A 2017, 5 (12), 5646-5660.

15. Shi, J.; Zhang, J.; Guo, J., Avoiding Pitfalls in Rechargeable Aluminum Batteries Research. ACS Energy Letters 2019, 4 (9), 2124-2129.

16. Jay, R.; Tomich, A. W .; Zhang, J.; Zhao, Y.; De Gorostiza, A.; Lavallo, V.; Guo, J., Comparative Study of $\operatorname{Mg}\left(\mathrm{CB}_{\| 1} \mathrm{H}_{12}\right)_{2}$ and $\mathrm{Mg}(\mathrm{TFSI})_{2}$ at the Magnesium/Electrolyte Interface. ACS Appl. Mater. Interfaces 2019, 11 (12), 11414-11420.

17. Rajput, N. N.; Qu, X.; Sa, N.; Burrell, A. K.; Persson, K. A., The coupling between stability and ion pair formation in magnesium electrolytes from first-principles quantum mechanics and classical molecular dynamics. J. Am. Chem. Soc. 2015, 137 (9), 341120.

18. Mandai, T.; Johansson, P., Haloaluminate-Free Cationic Aluminum Complexes: Structural Characterization and Physicochemical Properties. J. Phys. Chem. C 2016, 120 (38), 2128521292.

19. Ando, Y.; Kawamura, Y.; Ikeshoji, T.; Otani, M., Electrochemical reduction of an anion for ionic-liquid molecules on a lithium electrode studied by first-principles calculations. Chem. Phys. Lett. 2014, 612, 240-244.

20. $\mathrm{Xu}, \mathrm{K}$., Nonaqueous liquid electrolytes for lithium-based rechargeable batteries. Chem. Rev. 2004, 104 (10), 4303-4418.

21. Marsel, C. J.; Kalil, E. O.; Reidlinger, A.; Kramer, L., Preparation and Ignition Properties of Aluminum Alkyls. In METALORGANIC COMPOUNDS, AMERICAN CHEMICAL SOCIETY: 1959; Vol. 23, pp 172-183.

22. Martineau, C.; Taulelle, F.; Haouas, M., The use of ${ }^{2} \mathrm{Al}$ NMR to study aluminum compounds: a survey of the last 25 years. PATAI'S Chemistry of Functional Groups 2009, 1-51.

23. Gottlieb,H. E.; Kotlyar, V.; Nudelman, A., NMR chemical shifts of common laboratory solvents as trace impurities. The Journal of organic chemistry 1997, 62 (21), 7512-7515.

24. Parimalam, B. S.; MacIntosh, A. D.; Kadam, R.; Lucht, B. L., Decomposition Reactions of Anode Solid Electrolyte Interphase (SEI) Components with LiPF. J. Phys. Chem. C 2017, 121 (41), 22733-22738

25. Wilken, S.; Treskow, M.; Scheers, J.; Johansson, P.; Jacobsson, P., Initial stages of thermal decomposition of $\mathrm{LiPF}_{6}$-based lithium ion battery electrolytes by detailed Raman and NMR spectroscopy. RSC Advances 2013, 3 (37).

26. Barlowz, C., Reaction of Water with Hexafluorophosphates and with Li Bis (perfluoroethylsulfonyl) imide Salt. Electrochem. Solid-State Lett. 1999, 2 (8), 362-364.

27. Lux, S. F.; Chevalier, J.; Lucas, I. T.; Kostecki, R., HF Formation in LiPF $_{6}$-Based Organic Carbonate Electrolytes. ECS Electrochemistry Letters 2013, 2 (12), A121-A123.

28. Dahbi, M.; Nakano, T.; Yabuuchi, N.; Fujimura, S.; Chihara, K.; Kubota, K.; Son, J. Y.; Cui, Y. T.; Oji, H.; Komaba, S., Effect of Hexafluorophosphate and Fluoroethylene Carbonate on Electrochemical Performance and the Surface Layer of Hard Carbon for Sodium - Ion Batteries. ChemElectroChem 2016, 3 (11), 18561867.

29. Keyzer, E. N.; Glass, H. F.; Liu, Z.; Bayley, P. M.; Dutton, S. E.; Grey, C. P.; Wright, D. S., $\mathrm{Mg}\left(\mathrm{PF}_{6}\right)_{2}$-Based Electrolyte Systems: Understanding Electrolyte-Electrode Interactions for the Development of Mg-Ion Batteries. J. Am. Chem. Soc. 2016, 138 (28), 8682-5.

30. Shterenberg, I.; Salama, M.; Yoo, H. D.; Gofer, Y.; Park, J.-B.; Sun, Y.-K.; Aurbach, D., Evaluation of $\left(\mathrm{CF}_{3} \mathrm{SO}_{2}\right)_{2} \mathrm{~N}-(\mathrm{TFSI})$ 
Based Electrolyte Solutions for Mg Batteries. J. Electrochem. Soc. 2015, 162 (13), A7118-A7128.

31. Hess, A.; Kemnitz, E.; Lippitz, A.; Unger, W.; Menz, D., ESCA, XRD, and IR characterization of aluminum oxide, hydroxyfluoride, and fluoride surfaces in correlation with their catalytic activity in heterogeneous halogen exchange reactions. $J$. Catal. 1994, 148 (1), 270-280.

32. Yan, Y.; Helfand, M.; Clayton, C., Evaluation of the effect of surface roughness on thin film thickness measurements using variable angle XPS. Appl. Surf. Sci. 1989, 37 (4), 395-405.

33. Sarapatka, T., Palladium-induced charge transports with palladium/alumina/aluminum interface formation. J. Phys. Chem. 1993, 97 (43), 11274-11277. 


\section{Synthesis and electrochemical properties of an aluminum hexafluorophosphate electrolyte}

\section{- EXPERIMENTAL SECTION}

Synthesis of $\mathbf{A l}\left(\mathrm{PF}_{6}\right)_{3}$ : Due to the sensitivity to air and moisture, all manipulations were undertaken in an argon-filled glovebox $\left(<0.1 \mathrm{ppm} \mathrm{H}_{2} \mathrm{O}\right.$ and $\mathrm{O}_{2}$ ). Anhydrous dimethyl sulfoxide (DMSO, 99.9\%, SigmaAldrich) was further distilled with $\mathrm{CaH}_{2}$ prior to use. In addition, the water content of DMSO cannot be analyzed by Karl Fischer since it will alter the stoichiometry of the Karl Fischer reaction. Ammonium hexafluorophosphate $\left(\mathrm{NH}_{4} \mathrm{PF}_{6}, 99.98 \%\right.$, Sigma-Aldrich) was dried at ambient temperature for $24 \mathrm{~h}$ under vacuum. Trace amount of water content in $\mathrm{NH}_{4} \mathrm{PF}_{6}$ (below $10 \mathrm{ppm}$ in $0.5 \mathrm{M} \mathrm{NH}_{4} \mathrm{PF}_{6}$ in distilled tetraglyme) were detected. In the first step of synthesis, $\mathrm{NH}_{4} \mathrm{PF}_{6}(1.82 \mathrm{~g}, 11.17 \mathrm{mmol})$ was dissolved in DMSO $(8 \mathrm{~mL})$ in a glass vial. 4.2 equivalents $(46.91 \mathrm{mmol})$ of triethylaluminum (Et $3 \mathrm{Al})$ solution $(2.8 \mathrm{~mL}, 25 \mathrm{wt}$ \% in toluene, Sigma-Aldrich) was slowly added into the stirred solution of $\mathrm{NH}_{4} \mathrm{PF}_{6}$ in DMSO. A thorough degassing treatment under vacuum is essential to drive the reaction to completion. The produced ethane $\left(\mathrm{C}_{2} \mathrm{H}_{6}\right)$ and ammonia $\left(\mathrm{NH}_{3}\right)$ was evacuated by stirring the reaction mixture in DMSO at ambient temperature for $24 \mathrm{~h}$ under vacuum. $\mathrm{Al}\left(\mathrm{PF}_{6}\right)_{3}$ was obtained via recrystallization with toluene from the resultant solution as white powder. The obtained $\mathrm{Al}\left(\mathrm{PF}_{6}\right)_{3}$ was dried under vacuum for $12 \mathrm{~h}$ to remove residual toluene. $0.25 \mathrm{M} \mathrm{Al}\left(\mathrm{PF}_{6}\right)_{3}$ in DMSO was obtained by re-dissolve $\mathrm{Al}\left(\mathrm{PF}_{6}\right)_{3}$ in $\mathrm{DMSO}$ under agitation for 3 days to make the salt fully dissociated.

Single crystal X-ray Diffraction: Single crystal X-ray diffraction data were collected on a Bruker-AXS Apex II diffractometer with an Apex II CCD detector using Mo $K_{\alpha}$ radiation $(\lambda=0.71073 \AA)$ from a finefocus sealed tube source. Data were collected at $100 \mathrm{~K}$ by performing $0.5^{\circ} \varphi$ - and $\omega$-scans, integrated using SAINT, ${ }^{1}$ and absorption corrected using SADABS. ${ }^{2}$ The structure was solved by direct methods using SHELXT $^{3}$ and refined against $F^{2}$ on all data by full-matrix least squares with SHELXL-2018/3 following established refinement strategies. ${ }^{5}$ One hexafluorophosphate anion resides on and is disordered over a special position whose symmetry is not fulfilled by the molecule. In light of this disorder, the displacement parameters of the six fluorine atoms were kept isotropic, made equivalent, and allowed to refine freely, all non-hydrogen atoms were refined anisotropically. All hydrogen atoms were included into the model at geometrically calculated positions and refined using a riding model. The isotropic displacement parameters of all hydrogen atoms were fixed to 1.2 times the $U$ value of the atoms they are linked to (1.5 times for methyl groups). Crystal and data quality details, as well as a summary of the residual refinement values, are listed in

Table S1. 
NMR Spectroscopy: Liquid-state NMR spectra were acquired using a Bruker NEO 400 spectrometer with a $9.4 \mathrm{~T}$ narrow-bore superconducting magnet $\left({ }^{27} \mathrm{Al}\right.$ at $104.26 \mathrm{MHz},{ }^{1} \mathrm{H}$ at $400.13 \mathrm{MHz},{ }^{19} \mathrm{~F}$ at $376.50 \mathrm{MHz}$, ${ }^{31} \mathrm{P}$ at $242.83 \mathrm{MHz}$ ). All samples were prepared by dissolving $0.1 \mathrm{~mL}$ sample in $0.6 \mathrm{~mL}$ acetonitrile- $\mathrm{d}_{3}$ $\left(\mathrm{CD}_{3} \mathrm{CN}\right)$ solvent and sealed in a 5-mm standard NMR tube in an argon-filled glovebox. All NMR experiments were conducted at ambient temperature. ${ }^{27} \mathrm{Al},{ }^{1} \mathrm{H},{ }^{19} \mathrm{~F}$, and ${ }^{31} \mathrm{P}$ NMR chemical shifts are calibrated to the reference of 1.0 M aluminum chloride dissolved in $\mathrm{D}_{2} \mathrm{O}$ (99.9 atom\% D, Sigma-Aldrich), 1 M tetramethylsilane, $1 \mathrm{M}$ trichlorofluoromethane, and $85 \% \mathrm{H}_{3} \mathrm{PO}_{4}$ in $\mathrm{H}_{2} \mathrm{O}$, respectively.

Surface characterizations: The X-ray photoelectron spectroscopy (XPS) was conducted with a high sensitivity Kratos AXIS Supra with monochromatic $\mathrm{Al}(\mathrm{K} \alpha)$ radiation $(1486.7 \mathrm{eV})$. The emission current for excitation was $15 \mathrm{~mA}$. The etching of the sample for depth profiling measurements was performed with 5 $\mathrm{keV} \mathrm{Ar}{ }^{+}$sputtering. All XPS spectra were analyzed by the CasaXPS software using the carbon 1s peak at $284.8 \mathrm{eV}$ (adventitious carbon) as the reference. The XPS sample was first rinsed with freshly distilled DMSO three times to remove the residue of the reactants, and then rinsed with an adequate amount of anhydrous toluene to remove residual DMSO followed by evaporating the toluene. The sample rinsing and solvent evaporation were performed in an argon-filled glovebox. The XPS samples were transferred and loaded under argon continuously without exposure to ambient environment. The surface morphology and elemental composition of samples were characterized with scanning electron microscopy (SEM) and energy dispersive X-ray (EDX) spectroscopy.

GC/EI-MS analysis: The gas product from the chronopotentiometry experiments was identified by gas chromatography/electron ionization-mass spectrometry (GC/EI-MS). A gas-tight syringe was used to inject $30 \mu \mathrm{l}$ of the gas sample from the sealed three electrode cell into the GC/EI-MS system (Agilent 6890N GC coupled with 5975 MSD). Helium was used as the carrier gas at a flow rate of $1 \mathrm{~mL} \mathrm{~min}^{-1}$. Compound identification was performed using the NIST 2014 mass spectral database.

Electrochemical analyses: All electrochemical experiments were performed in the argon-filled glovebox using a Gamry potentiostat/galvanostat/ZRA (Reference 3000) at room temperature. Cyclic voltammetry $(\mathrm{CV})$ was carried out in three-electrode cells with a platinum $(\mathrm{Pt})$ working electrode (3mm disc, Gamry), $\mathrm{Al}$ wire (1 mm diameter, 99.9995\%, Alfa Aesar) reference electrode, and Al wire coil (2 mm diameter, 99.9995\%, Alfa Aesar) counter electrode. The Pt working electrode was polished with alumina particles (0.05 $\mu \mathrm{m})$ water dispersion on polishing pad and sonicated in ethanol, and then dried under vacuum. The Al reference and counter electrodes were scratched with stainless steel blaze to remove surface passivation layer in glovebox prior to every experiment. Copper $(\mathrm{Cu})$ foil ( $(\geq 99.9 \%$, Sigma-Aldrich) was used as the working electrode in the chronopotentiometry experiments. The $\mathrm{Cu}$ foil was first washed and sonicated with acetone for grease removal, and then immersed in the diluted sulfuric acid $\left(98 \% \mathrm{H}_{2} \mathrm{SO}_{4}: \mathrm{H}_{2} \mathrm{O}=1: 1\right.$ in volume ratio) for a few seconds to remove surface oxide layer. After that, it was washed by deionized water and then anhydrous ethanol. For immediate use, the fresh $\mathrm{Cu}$ foil was dried under vacuum in the antechamber of the 
glovebox and then baked for 3 mins on a hotplate in the glovebox to remove the residual ethanol. The Al reference and counter electrodes were treated as same as in the CV experiments.

Ionic conductivity measurement: The ionic conductivity of the electrolyte was measured by electrochemical impedance spectroscopy (EIS) using a customized two-electrode cell with constant length and electrode area. Two freshly cleaned $\mathrm{Cu}$ foils were used as electrodes on each side of the cell. Galvanostatic EIS experiment was conducted on this set-up with an AC current of $0.1 \mathrm{~mA}$ and frequency range from $10^{6}$ to $1 \mathrm{~Hz}$. The electrolyte ionic conductivity $\kappa$ can be calculated by the following Equations:

$$
\begin{gathered}
R=\rho \frac{l}{A} \\
\rho=\frac{l}{\kappa} \Rightarrow \kappa=\frac{l}{R A}
\end{gathered}
$$

where $R$ is the solution resistance, $\rho$ is the solution resistivity, $A$ is the electrode area, and $l$ is the distance between the electrodes.

a

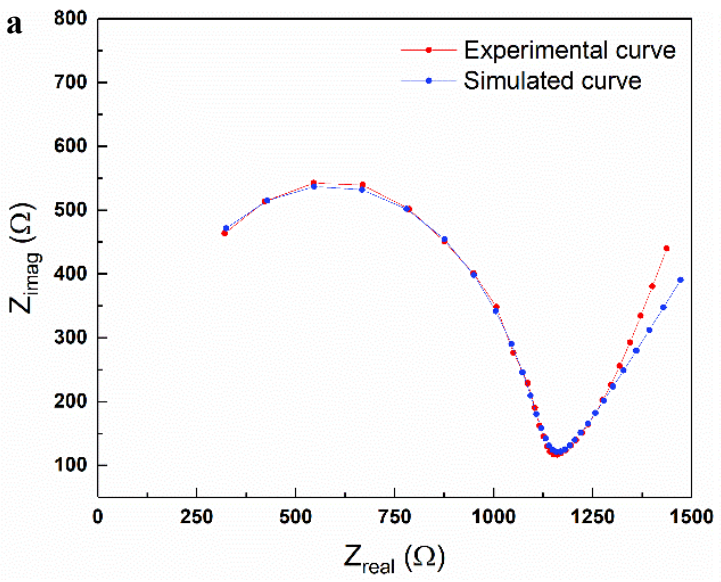

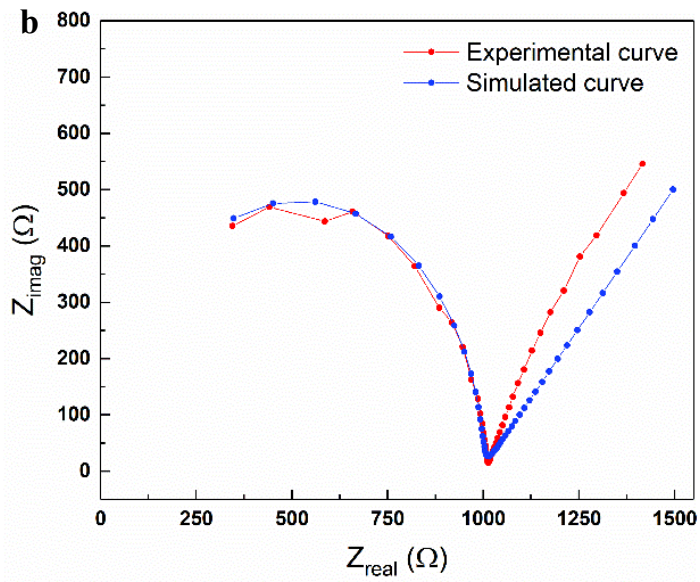

$\mathrm{C}_{\mathrm{dl}}$

c

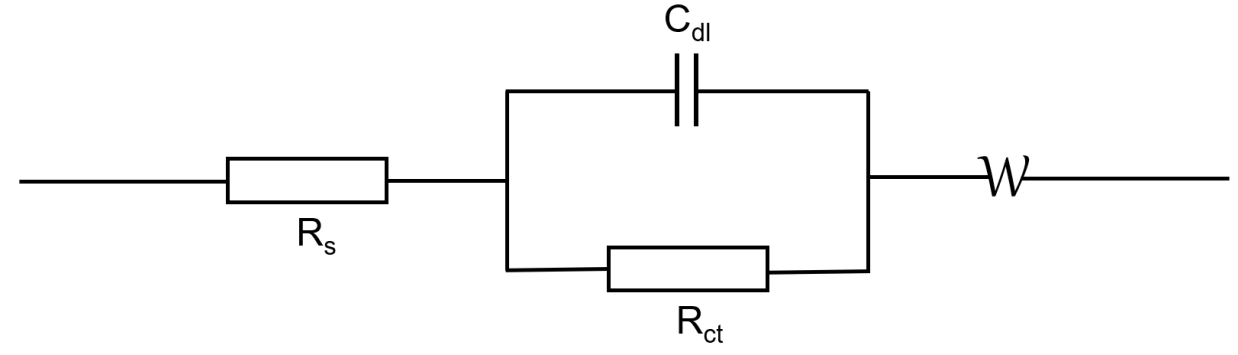

Figure S1. Nyquist plot for ionic conductivity measurement of (a) $0.25 \mathrm{M} \mathrm{Al}\left(\mathrm{PF}_{6}\right)_{3}$ in $\mathrm{DMSO}$, (b) $1 \mathrm{M} \mathrm{LiPF}_{6}$ in DMSO; (c) Equivalent circuit for simulation of the EIS spectra. 

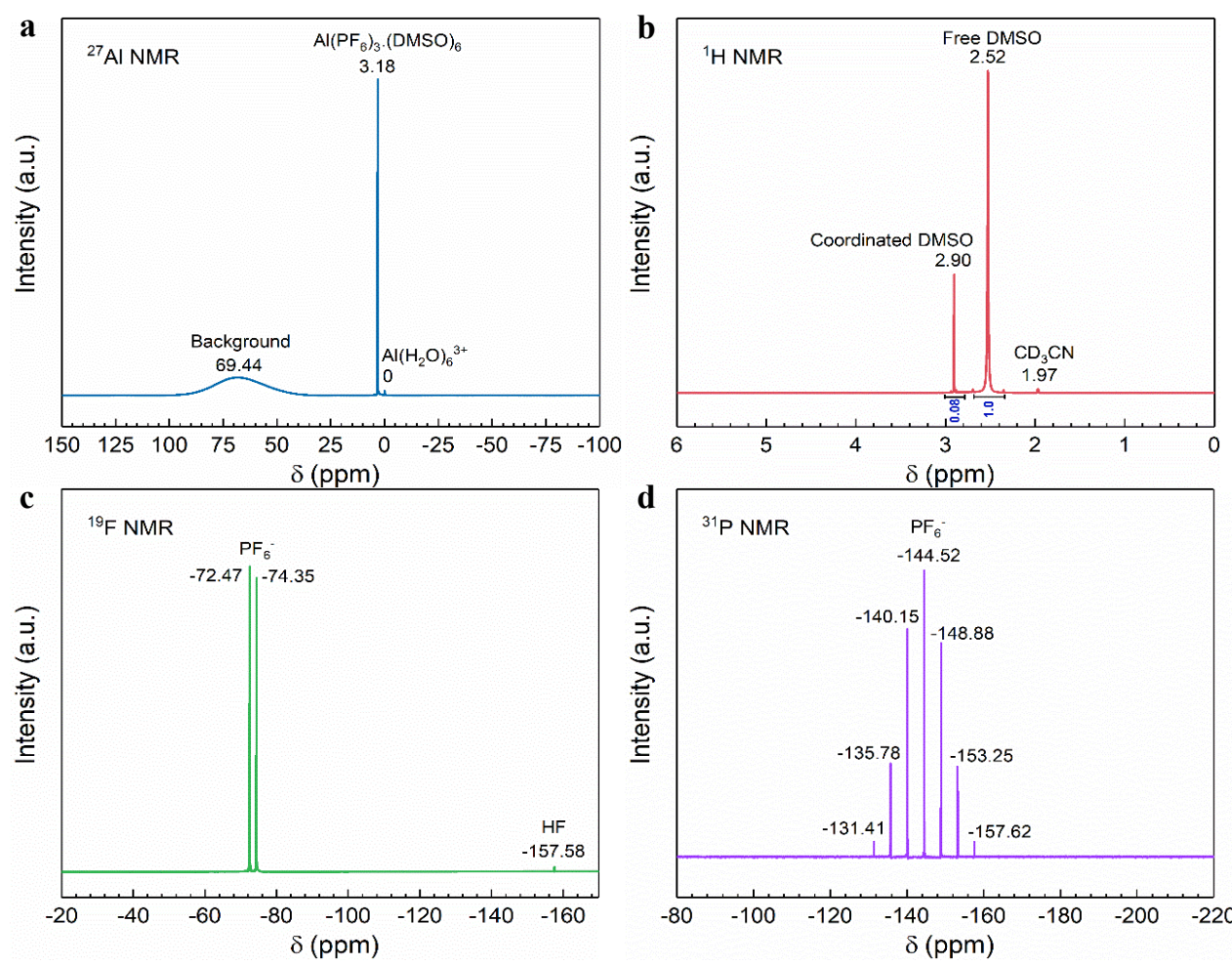

Figure S2. (a) ${ }^{27} \mathrm{Al}$, (b) ${ }^{1} \mathrm{H}$, (c) ${ }^{19} \mathrm{~F}$, and (d) ${ }^{31} \mathrm{P} \mathrm{NMR}$ spectra of $0.25 \mathrm{M} \mathrm{Al}\left(\mathrm{PF}_{6}\right)_{3}$ in DMSO after chronopotentiometry deposition.

In Figure S2a, a small peak at $0 \mathrm{ppm}$ in ${ }^{27} \mathrm{Al}$ NMR was detected, and it can be assigned to $\mathrm{Al}\left(\mathrm{H}_{2} \mathrm{O}\right)_{6}{ }^{3+}$ based on the chemical shift of ${ }^{27} \mathrm{Al}$ NMR reference. We suspect this was due to free $\mathrm{Al}^{3+}$ and $\mathrm{H}_{2} \mathrm{O}$ generated during electrodeposition by the reaction between $\mathrm{Al}_{2} \mathrm{O}_{3}$ and HF. In Figure $\mathbf{S 2 b}$, although the ${ }^{1} \mathrm{H}$ chemical shifts of the two DMSO-related peaks did not change after electrodeposition, the ratio between the coordinated DMSO and free DMSO decreased to 0.08 from 0.1, which indicates the consumption of $\mathrm{Al}^{3+}$ cation. In Figure S2c, the peak intensity of HF dramatically increased after deposition. Therefore, we hypothesize a "snowball" mechanism originated from the trace amount of water existing in the electrolyte, similar to the $\mathrm{LiPF}_{6}$ electrolytes: The $\mathrm{H}_{2} \mathrm{O}$ impurity react to $\mathrm{PF}_{6}{ }^{-}$to form $\mathrm{HF}$, which reacts to $\mathrm{Al}_{2} \mathrm{O}_{3}$ to produce $\mathrm{AlF}_{3}$ and $\mathrm{H}_{2} \mathrm{O}$. 

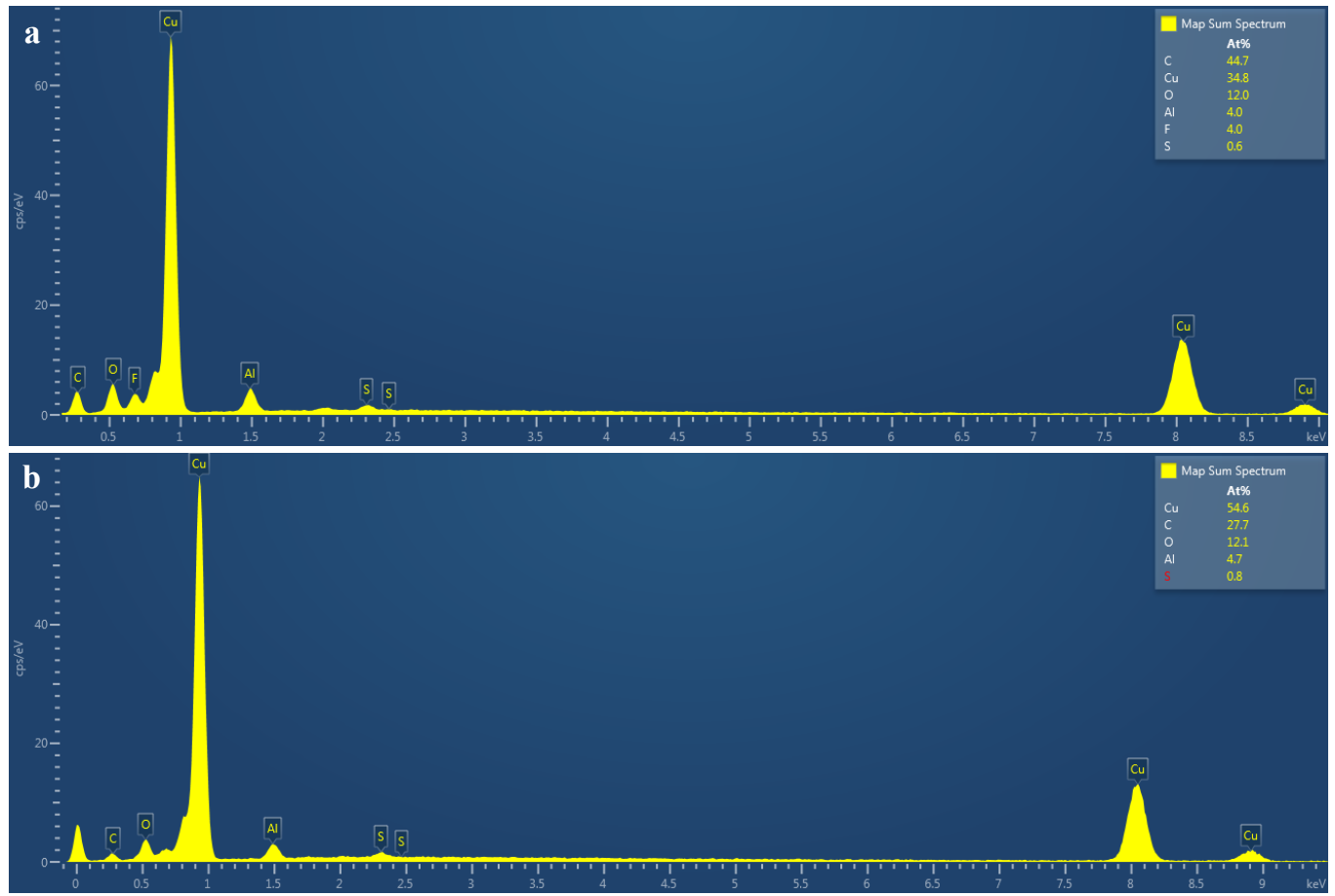

Figure S3. EDX spectra of $\mathrm{Al}$ deposit on $\mathrm{Cu}$ from $0.25 \mathrm{M} \mathrm{Al}\left(\mathrm{PF}_{6}\right)_{3}$ in $\mathrm{DMSO}$ (a) without and (b) with 250 ppm $\mathrm{Et}_{3} \mathrm{Al}$ additive.
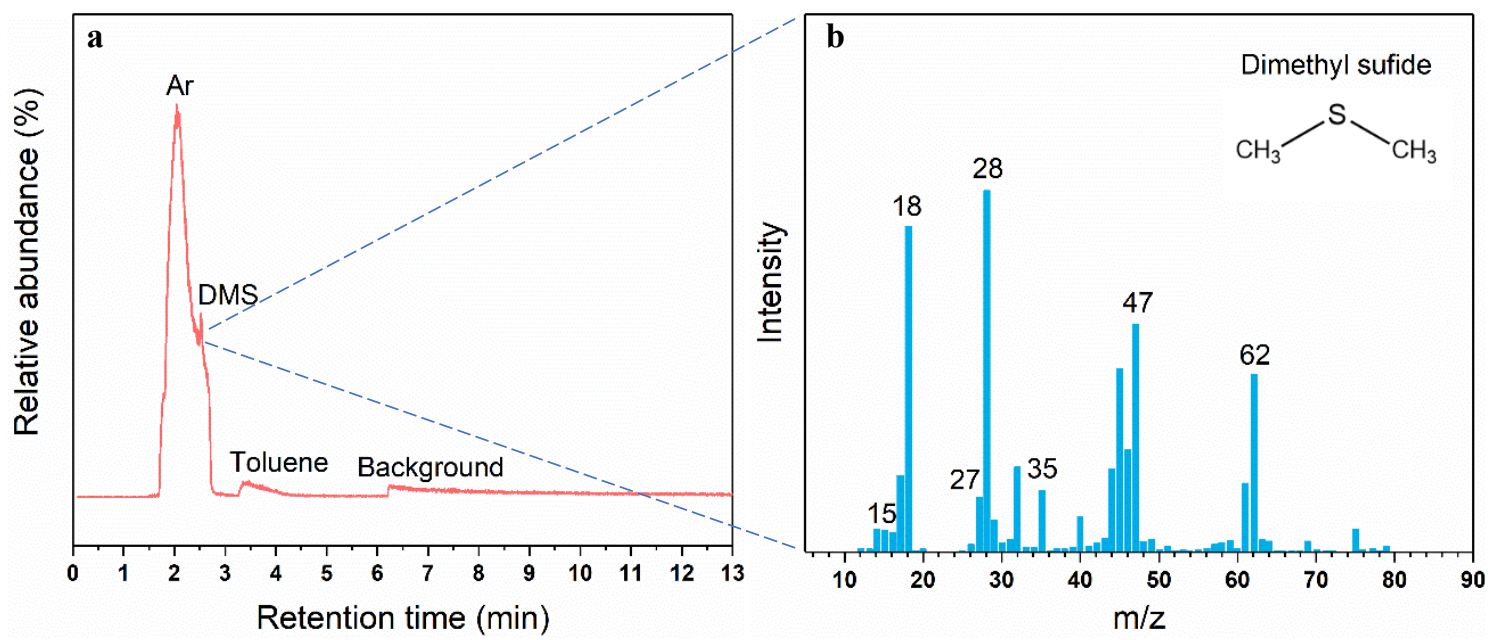

Figure S4. (a) GC chromatogram; (b) EI-MS of gas product during electrodeposition from $0.25 \mathrm{M} \mathrm{Al}\left(\mathrm{PF}_{6}\right)_{3}$ in DMSO without $\mathrm{Et}_{3} \mathrm{Al}$ additive. 
Table S1. Crystal data and structure refinement of $\mathrm{Al}\left(\mathrm{PF}_{6}\right)_{3} \cdot(\mathrm{DMSO})_{6}$.

\begin{tabular}{|c|c|}
\hline Identification code & $\mathrm{Al}\left(\mathrm{PF}_{6}\right)_{3} \cdot(\mathrm{DMSO})_{6}$ \\
\hline Empirical formula & C12 H36 A1 F18 O6 P3 S6 \\
\hline Formula weight & 930.66 \\
\hline Temperature & $105(2) \mathrm{K}$ \\
\hline Wavelength & $0.71073 \AA$ \\
\hline Crystal system & Cubic \\
\hline Space group & Pn-3 \\
\hline Unit cell dimensions & $\begin{array}{l}\mathrm{a}=15.3081(3) \AA \mathrm{a}=90^{\circ} \\
\mathrm{b}=15.3081(3) \AA \mathrm{b}=90^{\circ} \\
\mathrm{c}=15.3081(3) \AA \mathrm{g}=90^{\circ}\end{array}$ \\
\hline Volume & $3587.3(2) \AA^{3}$ \\
\hline $\mathrm{Z}$ & 4 \\
\hline Density (calculated) & $1.723 \mathrm{Mg} / \mathrm{m}^{3}$ \\
\hline Absorption coefficient & $0.662 \mathrm{~mm}^{-1}$ \\
\hline $\mathrm{F}(000)$ & 1888 \\
\hline Crystal color & colourless \\
\hline Crystal size & $0.307 \times 0.253 \times 0.188 \mathrm{~mm}^{3}$ \\
\hline Theta range for data collection & 1.330 to $30.992^{\circ}$ \\
\hline Index ranges & $-22<=h<=22,-20<=k<=22,-21<=l<=21$ \\
\hline Reflections collected & 40068 \\
\hline Independent reflections & $1922[\mathrm{R}($ int $)=0.0285]$ \\
\hline Completeness to theta $=25.242^{\circ}$ & $99.9 \%$ \\
\hline Absorption correction & Semi-empirical from equivalents \\
\hline Refinement method & Full-matrix least-squares on $\mathrm{F}^{2}$ \\
\hline Data / restraints / parameters & 1922 / 92 / 103 \\
\hline Goodness-of-fit on $\mathrm{F}^{2}$ & 1.086 \\
\hline Final $R$ indices $[I>2 \operatorname{sigma}(I)=1821$ data $]$ & $\mathrm{R} 1=0.0207, \mathrm{wR} 2=0.0561$ \\
\hline $\mathrm{R}$ indices (all data, $0.69 \AA$ ) & $\mathrm{R} 1=0.0226, \mathrm{wR} 2=0.0575$ \\
\hline Largest diff. peak and hole & 0.330 and $-0.276 \mathrm{e} . \AA^{-3}$ \\
\hline CCDC deposition number & 1985065 \\
\hline
\end{tabular}


- REFERENCES

1. SAINT, version 8.34A, Bruker (2012), Bruker AXS Inc., Madison, Wisconsin, USA.

2. SADABS, version 2012/1, Bruker (2012), Bruker AXS Inc., Madison, Wisconsin, USA.

3. Sheldrick, G. M., Acta Cryst. 2015, A71, 3-8

4. Sheldrick, G. M., Acta Cryst. 2015, C71, 3-8.

5. Müller, P. Crystallography Reviews 2009, 15, 57-83. 